\title{
Ammonia is the Preferred Nitrogen Source in Several Rhizobia
}

\author{
By P. S. POOLE, ${ }^{*}+$ M. J. DILWORTH AND A. R. GLENN \\ Nitrogen Fixation Research Group, School of Environmental and Life Sciences, \\ Murdoch University, Murdoch 6150, Western Australia
}

(Received 6 October 1986; revised 16 February 1987)

When presented with an equimolar mixture of ammonia and L-glutamate, batch cultures of Rhizobium leguminosarum MNF3841 and ' $R$. trifolii' ( $R$. leguminosarum biovar trifolii) TAl used ammonia at a significantly faster rate than L-glutamate. The cowpea Rhizobium strain NGR234, however, used L-glutamate at a marginally faster rate than ammonia. $R$. leguminosarum MNF3841 also grew faster on ammonia than on L-glutamate as the nitrogen source.

Chemostat cultures of $R$. leguminosarum MNF3841 limited for phosphate did not release excess ammonia when grown on mannitol/L-glutamate, showing that L-glutamate catabolism was tightly regulated to meet the cells' nitrogen requirement. Further, the rate of consumption of ammonia was similar to that for L-glutamate when either was supplied as the sole nitrogen source. However, with L-histidine or L-alanine as a nitrogen source, large quantities of excess ammonia were released. When chemostat cultures of $R$. leguminosarum MNF3841 were supplied with an equimolar mixture of ammonia and L-glutamate, $89-100 \%$ of the nitrogen consumed was ammonia. Similarly, with mixtures of L-glutamate/L-histidine or L-glutamate/L-alanine, almost no L-glutamate was consumed, a result attributable to the release of excess ammonia from either L-histidine or L-alanine. The use of ${ }^{14} \mathrm{C}$-labelled fructose or L-glutamate showed that the intra- and extracellular L-glutamate pools were isolated, indicating that the ammonia preference must be exerted by a restriction in L-glutamate transport. L-Glutamate transport rates were low in chemostats containing L-glutamate $/ \mathrm{NH}_{4} \mathrm{Cl}$, an effect attributable in part to a significant repression of synthesis of the L-glutamate transport system by ammonia.

\section{INTRODUCTION}

In the legume nodule, bacteroids of the genus Rhizobium reduce $\mathrm{N}_{2}$ to ammonia, but they appear unable to assimilate it into amino acids (Bergersen \& Turner, 1967; Brown \& Dilworth, 1975; Kurz et al., 1975). Instead the ammonia is exported to the plant cytosol where it is assimilated into organic nitrogen compounds (Brown \& Dilworth, 1975; Kurz et al., 1975; Scott et al., 1976). It has also been reported that at least some free-living rhizobia are poor at assimilating ammonia and have a marked preference for an organic nitrogen source such as L-glutamate (Bergersen, 1961; O’Gara \& Shanmugam, 1976a, b; Tubb, 1976; Ludwig, 1978). However, several groups have nevertheless been able to grow a wide range of rhizobia on ammonia as the sole nitrogen source (Brown \& Dilworth, 1975; Ratcliffe et al., 1983; Botsford 1984; Mohapatra \& Gresshoff, 1984). Whether there is any preference is important because it may give an insight into the regulation of nitrogen metabolism in Rhizobium. Investigating this preference is best approached by the use of chemostat culture, where meaningful specific nitrogen consumption rates and rates of ammonia liberation from organic nitrogen sources can be measured.

The following study presents an initial screening of several rhizobia for nitrogen preference in batch culture, followed by a detailed chemostat study of $R$. leguminosarum MNF3841.

† Present address: Microbiology Unit, Department of Biochemistry, University of Oxford, South Parks Road, Oxford OXI 3QU, UK. 


\section{METHODS}

Organisms. Rhizobium leguminosarum MNF3841 is described by Glenn et al. (1980), ' $R$. trifolii' ( $R$. leguminosarum biovar trifolii) TA1 by Chen et al. (1984) and cowpea Rhizobium NGR234 by Glenn \& Dilworth (1981).

Media. Bacteria were grown at $28^{\circ} \mathrm{C}$ in the liquid minimal salts (MS) medium of Brown \& Dilworth (1975), with phosphate at $0.4 \mathrm{~mm}$ and with the pH maintained at 7.0 with $20 \mathrm{mM}$-HEPES in chemostats and $40 \mathrm{~mm}$-HEPES in batch cultures. Stocks were maintained on minimal salts slope cultures with $10 \mathrm{~mm}$-mannitol and $5 \mathrm{mM}-\mathrm{NH}{ }_{4} \mathrm{Cl}$.

Nitrogen consumption in batch culture. Rhizobial cells were removed with deionized water from 2-d-old slope culture, and a $0.5 \%$ inoculum was added to $100 \mathrm{ml}$ minimal salts medium with $10 \mathrm{~mm}$-mannitol and nitrogen

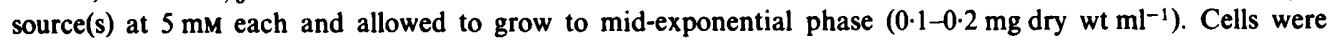
harvested aseptically by centrifugation; the supernatants were discarded, and the bacteria were resuspended in fresh medium of the same composition, except that each nitrogen source was at $1.5 \mathrm{~mm}$. Samples $(2.0 \mathrm{ml})$ were removed at approximately $0.75 \mathrm{~h}$ intervals for measurement of culture density; after pelleting the cells by centrifugation the supernatants were analysed for concentrations of nitrogen compounds.

Dry weights were determined by measuring the $\mathrm{OD}_{600}$ of cultures and relating the values to a previously constructed standard curve of dry weight versus $\mathrm{OD}_{600}$.

Nitrogen consumption rates in chemostat culture. Chemostats were set up with $70 \mathrm{ml}$ working volumes and a dilution rate of $0.1 \mathrm{~h}^{-1}$ as described by Poole et al. (1985). The cultures were grown under phosphate limitation $(0.08 \mathrm{mM})$, with either mannitol $(10 \mathrm{mM})$ or fructose $(10 \mathrm{~mm})$ as the carbon source. Nitrogen source $(\mathrm{s})(3 \mathrm{~mm})$ and fructose were filter-sterilized and added aseptically to autoclaved minimal salts. To confirm phosphate limitation, alkaline phosphatase activity was measured as described by Smart $e$ t al. (1984). From steady-state cultures, as assessed by a constant cell density, $7.0 \mathrm{ml}$ of cells were sampled daily and centrifuged. Supernatants were removed and frozen for later assay.

Consumption rates have been arbitrarily assigned a negative value to distinguish them from production rates.

Radioisotopes. $\mathrm{L}-\left[\mathrm{U}-{ }^{14} \mathrm{C}\right] \mathrm{Glutamate}\left(10.9 \mathrm{GBq} \mathrm{mmol}^{-1}\right)$ was from New England Nuclear, and $\mathrm{D}-\left[\mathrm{U}-{ }^{14} \mathrm{C}\right]-$ fructose $\left(12.6 \mathrm{GBq} \mathrm{mmol}^{-1}\right)$ from Amersham.

Addition of radioisotopes to chemostat. Two mannitol $(10 \mathrm{~mm})$ chemostats were set up, one with L-alanine/ L-glutamate and the second with L-histidine/L-glutamate as their respective nitrogen sources. After establishing steady-state growth, $0.148 \mathrm{MBq} \mathrm{L}-\left[\mathrm{U}-{ }^{14} \mathrm{C}\right]$ glutamate was injected into each sample reservoir (1.51) and the chemostat allowed to equilibrate for $48 \mathrm{~h}$. Samples $(5.0 \mathrm{ml})$ were then removed daily from the growth vessels, Millipore filtered and washed twice with $3.0 \mathrm{ml}$ minimal salts. These filters were then added to scintillant as described by Poole et al. (1985).

A chemostat containing fructose with $\mathrm{NH}_{4} \mathrm{Cl} / \mathrm{L}$-glutamate as the nitrogen sources was allowed to reach steady state before adding $1.85 \mathrm{MBq}\left[\mathrm{U}^{14} \mathrm{C}\right.$ ]fructose to the reservoir (1.5 l). After allowing $48 \mathrm{~h}$ for equilibration, sampling proceeded from the growth vessel as above. Bacteria were removed by centrifugation and the supernatants analysed by paper chromatography.

Paper chromatography. Sample supernatants removed from a chemostat containing fructose were applied to $45 \mathrm{~cm}$ sheets of Whatman $3 \mathrm{M}$ chromatography paper and the components separated overnight in phenol $(500 \mathrm{~g}$ in $125 \mathrm{ml}$ water)/ethanol/water $(15: 4: 1$, by vol.). The L-glutamate was located by spraying the chromatogram with ninhydrin $(0.1 \%, \mathrm{w} / \mathrm{v}$, in ethanol) and the sheets were cut into $1 \mathrm{~cm}$ sections before being put into scintillation fluid for counting. $R_{\mathrm{F}}$ values were also determined for standards of $\mathrm{L}-\left[{ }^{14} \mathrm{C}\right]$ glutamate and $\left[{ }^{14} \mathrm{C}\right]$ fructose.

Analytical methods. Ammonia was determined by the phenol/hypochlorite method of Fawcett \& Scott (1960). L-Histidine was determined by the method of Ray (1967) as used by Dilworth et al. (1983). L-Glutamate was determined enzymically by the method of Bernt \& Bergmeyer (1974), and L-aspartate by the procedure of Bergmeyer et al. (1974).

L-Alanine was determined in a final volume of $1.5 \mathrm{ml}$ containing: $75 \mu \mathrm{mol}$ glycine buffer ( $\mathrm{pH} 9.0$ ), $60 \mu \mathrm{mol}$ hydrazine monohydrate, $4 \mu \mathrm{mol} \mathrm{NAD}{ }^{+}$and 0.5 unit of $L$-alanine dehydrogenase. These were incubated and read as for the L-glutamate assay of Bernt \& Bergmeyer (1974). Ammonia had no effect on the assays of L-glutamate or any of the other amino acids. Protein was determined by the Lowry method using bovine serum albumin as a standard.

Transport. Cells of $R$. leguminosarum MNF384I were harvested and washed, and L-glutamate transport rates were measured as described by Poole et al. (1985).

\section{RESULTS}

\section{Nitrogen source preference of cells in batch culture}

R. leguminosarum MNF3841 grew with a mean generation time of $4.8 \mathrm{~h}$ and $3.8 \mathrm{~h}$, respectively, on mannitol/L-glutamate and mannitol/ammonia. To determine if this small difference in growth rate resulted in a preference for either nitrogen source, cells of MNF3841 were grown in a minimal salts medium with an equimolar mixture of $\mathrm{NH}_{4} \mathrm{Cl}$ and L-glutamate as the nitrogen sources. Ammonia was consumed at an initial rate of $-2.08 \mu \mathrm{mol} \mathrm{h}^{-1}(\mathrm{mg} \mathrm{dry} \mathrm{wt})^{-1}$ 
Table 1. Nitrogen utilization by $R$. leguminosarum MNF3841 in chemostat culture

\begin{tabular}{|c|c|c|c|c|c|c|}
\hline \multirow{2}{*}{$\begin{array}{l}\text { Carbon } \\
\text { source }\end{array}$} & \multirow{2}{*}{$\begin{array}{l}\text { Nitrogen } \\
\text { source(s) }\end{array}$} & \multicolumn{5}{|c|}{$\begin{array}{l}\text { Utilization or production rate } \\
{\left[\mu \mathrm{mol} \mathrm{h}^{-1}(\mathrm{mg} \text { dry } \mathrm{wt})^{-1}\right]}\end{array}$} \\
\hline & & L-Aspartate & L-Alanine & L-Histidine & L-Glutamate & $\mathrm{NH}_{3}$ \\
\hline Mannitol & $\mathrm{NH}_{4} \mathrm{Cl}$ & & & & & $-0.669 \pm 0.021$ \\
\hline Mannitol & L-Glutamate & & & & $-0.611 \pm 0.032$ & \\
\hline Mannitol & L-Alanine & & $-0.854 \pm 0.026$ & & & $+0.322 \pm 0.028$ \\
\hline Mannitol & $\begin{array}{l}\text { L-Glutamate/ } \\
\mathrm{NH}_{4} \mathrm{Cl}\end{array}$ & & & & 0 & \\
\hline $\begin{array}{l}\text { Mannitol } \\
\text { Mannitol }\end{array}$ & $\begin{array}{l}\text { L-Glutamate/ } \\
\text { L-Alanine } \\
\text { L-Glutamate/ }\end{array}$ & & $-0.927 \pm 0.01$ & & 0 & $-0.404 \pm 0.031$ \\
\hline Mannitol & $\begin{array}{r}\text { L-Histidine } \\
\text { L-Glutamate/ }\end{array}$ & & & $-0.480 \pm 0.025$ & 0 & $+0.842 \pm 0.046$ \\
\hline Fructose & $\begin{array}{c}\text { L-Aspartate } \\
\text { L-Glutamate/ } \\
\mathrm{NH}_{4} \mathrm{Cl}\end{array}$ & $-0.438 \pm 0.005$ & & & $\begin{array}{l}-0.304 \pm 0.009 \\
-0.069 \pm 0.029\end{array}$ & $\begin{array}{c}0 \\
-0.586 \pm 0.05\end{array}$ \\
\hline
\end{tabular}

* Production has been assigned a positive value and consumption a negative value. All values are shown \pm the standard error of the mean determined from at least three samples.

until completely used, while L-glutamate consumption varied from an initial rate of zero to $-0.74 \mu \mathrm{mol} \mathrm{h}^{-1}(\mathrm{mg} \text { dry } \mathrm{wt})^{-1}$. This preference for ammonia was not restricted to $R$. leguminosarum, since ' $R$. trifolii' TAl consumed ammonia at an initial rate of $-1.66 \mu \mathrm{mol} \mathrm{h}^{-1}$ (mg dry wt $)^{-1}$, while L-glutamate was not consumed at all. Of several other rhizobia tested [ $R$. leguminosarum WU235, ' $R$. phaseoli' ( $R$. leguminosarum biovar phaseoli) WU155, $R$. meliloti WU38 and cowpea Rhizobium NGR234], only Rhizobium NGR234 consumed L-glutamate at a slightly higher rate $\left[-1.64 \mu \mathrm{mol} \mathrm{h}^{-1}(\mathrm{mg} \text { dry wt) })^{-1}\right]$ than ammonia $\left[-1.26 \mu \mathrm{mol} \mathrm{h}^{-1}(\mathrm{mg}\right.$ dry $\mathrm{wt}^{-1}$ ]. To examine further the general preference for ammonia a detailed chemostat study of $R$. leguminosarum MNF3841 was conducted.

\section{Nitrogen consumption by strain MNF3841 in chemostat culture}

Table 1 shows the nitrogen consumption rates for $R$. leguminosarum MNF3841 when grown with $10 \mathrm{mM}$-mannitol as a carbon source and several different sources of nitrogen at $3 \mathrm{mM}$ in the reservoir. For cells with either ammonia or L-glutamate as the nitrogen source, the rate of consumption of ammonia $\left[-0.67 \mu \mathrm{mol} \mathrm{h}^{-1}(\mathrm{mg} \text { dry wt })^{-1}\right]$ was similar to the rate of consumption of L-glutamate $\left[-0.61 \mu \mathrm{mol} \mathrm{h}^{-1}\left(\mathrm{mg}^{\mathrm{dry} \mathrm{wt}}\right)^{-1}\right]$. Significantly, this indicates that L-glutamate was not being consumed in excess of the cells' nitrogen requirement, a contention supported by the absence of detectable ammonia in the growth vessel of the mannitol/ L-glutamate chemostats. The consumption rate of ammonia in batch culture $\left[-2.08 \mu \mathrm{mol} \mathrm{h}^{-1}\right.$ (mg dry wt $)^{-1}$ ] was threefold higher than that in chemostat culture. When the mean generation time of between $3.5 \mathrm{~h}$ and $4 \mathrm{~h}$ in batch culture is compared to the theoretical generation time in the chemostat culture of $6.9 \mathrm{~h}$, a higher specific nitrogen consumption rate is not unexpected.

Chemostats with $\mathrm{L}$-alanine as the nitrogen source released large quantities of excess ammonia into the growth vessel (Table 1). Predictably, the consumption rate of L-alanine $\left[-0.85 \mu \mathrm{mol} \mathrm{h}^{-1}\right.$ (mg dry $\left.w t)^{-1}\right]$ was significantly above the rate for either ammonia or L-glutamate.

\section{Nitrogen preference in chemostats containing mixed nitrogen sources}

Since it was apparent that under the growth conditions used, L-glutamate did not give rise to excess ammonia (Table 1) it was possible to mix L-glutamate with $\mathrm{NH}_{4} \mathrm{Cl}$ in the same chemostat. The rates of utilization of both were then measured, without the complication of excess ammonia derived from L-glutamate entering the ammonia pool. With mannitol (10 mM) as a carbon source in chemostats containing L-glutamate $/ \mathrm{NH}_{4} \mathrm{Cl}$, there was no detectable L-glutamate consumption by $R$. leguminosarum MNF3841, while ammonia was consumed at a rate only $14 \%$ lower than when it was the sole nitrogen source (Table 1 ). In those chemostats where mannitol was replaced by fructose, L-glutamate was consumed at $11 \%$ of the total nitrogen consumption rate. 
Detection of L-glutamate consumption at this level is at the limit of sensitivity of the assay and tends to be associated with a high error. The failure to detect L-glutamate consumption in mannitol-containing chemostats is therefore unlikely to reflect any intrinsic difference between mannitol and fructose as carbon sources.

When L-glutamate was mixed with either L-alanine or L-histidine in mannitol-containing chemostats, there was no L-glutamate utilization and L-alanine was consumed at essentially the same rate as when it was the sole nitrogen source (Table 1 ). Both the L-glutamate/L-histidine and the L-glutamate/L-alanine chemostats produced excess ammonia and, as L-glutamate was not apparently consumed, it presumably arose from the catabolism of L-histidine and L-alanine.

Since cultures containing L-histidine/L-glutamate or L-alanine/L-glutamate as nitrogen sources did not show L-glutamate consumption, it was of interest to see if other amino acids would suppress L-glutamate consumption. To test this, a mannitol chemostat was set up containing L-glutamate and L-aspartate, an amino acid whose transport and catabolism are closely linked to those of L-glutamate (Poole et al., 1985). L-Glutamate and L-aspartate represented $41 \%$ and $59 \%$, respectively, of the total nitrogen consumption, while ammonia was not excreted (Table 1). Whether an amino acid does or does not prevent L-glutamate consumption therefore appears to be determined by whether excess ammonia is released from it.

\section{Measurement of glutamate incorporation}

While chemostats with mannitol as a carbon source and combinations of L-glutamate with either $\mathrm{NH}_{4} \mathrm{Cl}$ or $\mathrm{L}$-histidine or L-alanine showed no significant consumption of L-glutamate, this does not prove that there had been no consumption of exogenous glutamate. Since the L-glutamate transport system is capable of exchange (Poole et al., 1985), intracellularly synthesized glutamate may have been exported to the extracellular environment at a rate sufficient to balance the uptake rate.

To measure the incorporation of exogenously supplied L-glutamate directly, $\mathrm{L}-\left[{ }^{14} \mathrm{C}\right]$ glutamate was added to the reservoir of chemostats containing either L-histidine/L-glutamate or L-alanine/L-glutamate. Cells of strain MNF3841 in the chemostat containing L-alanine/ $\mathrm{L}$-glutamate incorporated the $\mathrm{L}-\left[{ }^{14} \mathrm{C}\right]$ glutamate at an apparent rate of $0.049 \mu \mathrm{mol} \mathrm{h}^{-1}$ (mg dry wt $)^{-1}$, which was $8 \%$ of the consumption rate when L-glutamate was supplied as the sole nitrogen source. However, no measurement was made of any respired ${ }^{14} \mathrm{CO}_{2}$ and the real labelling may have been higher. Cells from the chemostat containing $L$-histidine/L-glutamate had an apparent incorporation rate of $0.057 \mu \mathrm{mol} \mathrm{h}^{-1}(\mathrm{mg} \mathrm{dry} \mathrm{wt})^{-1}$, or $9 \%$ of the consumption rate when L-glutamate was the sole nitrogen source. This result, where L-glutamate incorporation has been measured by a highly sensitive radiometric technique, suggests that the similarly small consumption seen in fructose-containing chemostats is real. For both chemostats, the specific activities of the radioactive L-glutamate in the growth vessel and in the reservoir were not detectably different.

\section{Measurement of the exchange between the internal and external glutamate pools}

The low incorporation rates of glutamate into cells of $R$. leguminosarum MNF3841, and the low or zero L-glutamate consumption rates, indicated that the intracellular and extracellular L-glutamate pools are substantially isolated. As a direct measure of this, $\mathrm{D}-\left[\mathrm{U}-{ }^{14} \mathrm{C}\right]$ fructose was introduced into the reservoir of a chemostat containing fructose $/ \mathrm{NH}_{4} \mathrm{Cl} / \mathrm{L}$-glutamate and the supernatants obtained from the growth vessel were analysed by paper chromatography after the cellular material had been removed. Apart from $22 \%$ of the label left on the origin, the remaining $78 \%$ of ${ }^{14} \mathrm{C}$ label was present in the fructose. Since the L-glutamate was clearly separated from either of these radioactive areas, and was itself unlabelled, there had been no export of intracellularly synthesized L-glutamate.

\section{Transport rates}

In the presence of ammonia the isolation of the intra- and extracellular pools of L-glutamate and low incorporation rates of this amino acid may be due to kinetic inhibition and/or complete repression of synthesis of the glutamate transport system. Since ammonia is unable to inhibit the 
transport of L-glutamate by what appears to be a common amino acid carrier (Poole et al., 1985), the possibility that amonia repressed synthesis of this transport system was investigated. Cells of strain MNF3841 initially grown in chemostat culture under ammonia limitation had an L-glutamate transport rate of $38 \mathrm{nmol} \mathrm{m^{-1 }}$ (mg protein $)^{-1}$. When L-glutamate was added to the reservoir so that the cells were nitrogen limited on both ammonia and L-glutamate, the transport rate for L-glutamate only increased by $29 \%$ to $49 \mathrm{nmol} \mathrm{min} \mathrm{(mg} \mathrm{protein)}{ }^{-1}$. Addition of excess ammonia and L-glutamate ( $9 \mathrm{mM}$ of each in the reservoir), which caused a change to phosphate limitation, decreased the transport rate to $2.8 \mathrm{nmol} \mathrm{min}^{-1}(\mathrm{mg} \text { protein })^{-1}$.

\section{DISCUSSION}

The similar consumption rates found for ammonia and L-glutamate when each was the sole nitrogen source and the absence of excess ammonia in chemostats containing L-glutamate show that L-glutamate catabolism is tightly regulated (Table 1). It was also shown that ammonia repressed synthesis of the L-glutamate transport system. These results can be contrasted to those obtained with chemostats containing L-alanine or L-histidine, where there was a clear deregulation of catabolism with the consumption of these amino acids in excess of that required solely to satisfy the cells' nitrogen requirement. Presumably these amino acids must have transport and catabolic systems that are not as tightly regulated by ammonia as those for L-glutamate.

With mixtures of ammonia and L-glutamate as the nitrogen sources, $R$. leguminosarum MNF3841 utilized ammonia preferentially, with L-glutamate contributing at most $11 \%$ of the total nitrogen consumed (Table 1). Similar results were obtained if L-alanine or L-histidine replaced ammonia in the reservoir. This apparent preference for L-histidine or L-alanine over L-glutamate is expected because of the lack of tight regulation on the catabolism of these amino acids, with large quantities of excess ammonia being released. Considering that ammonia suppresses L-glutamate consumption it is perhaps not surprising that nitrogen sources that release excess ammonia may also suppress L-glutamate utilization.

There are at least three main models to explain why the apparent L-glutamate consumption was low compared with ammonia. These are:

1. Ammonia stops L-glutamate utilization by inhibiting its incorporation inside the cell.

2. Ammonia represses the transport of exogenous L-glutamate into the cell.

3. The apparent absence of L-glutamate consumption results from the free exchange between the internal and external L-glutamate pools, such that the rate of export of L-glutamate, synthesized from ammonia and the carbon source, matches the rate of import from the outside.

The first explanation is unlikely because it would require that ammonia should be incorporated into amino acids independently of $\mathrm{L}$-glutamate. There are two principal reactions which would allow this: L-alanine dehydrogenase and aspartase. L-Alanine dehydrogenase, with its very high $K_{\mathrm{m}}$ for ammonia (Brown et al., 1974), is not thought to be important in bacterial ammonia assimilation, while aspartase is principally a catabolic enzyme and was not present under these conditions (Poole et al., 1984). Of the other two models, the second predicts that the intra- and extracellular pools of L-glutamate are isolated, while the third requires their free exchange. Although amino acids were capable of exchanging during initial uptake (Poole et al., 1985), ${ }^{14} \mathrm{C}$ from the carbon source fructose was not detected in the external L-glutamate, providing strong evidence that the two pools were isolated during steady-state growth. This result was confirmed by the low rate of incorporation into cellular material of exogenously supplied L- $\left[{ }^{14} \mathrm{C}\right]$ glutamate. Such evidence is only compatible with ammonia or a product of its metabolism restricting the entry of L-glutamate at least partly by repression of the synthesis of its transport system, since ammonia had no direct effect on L- $\left[{ }^{14} \mathrm{C}\right]$ glutamate uptake (Poole et al., 1985) in short-term assays.

In a phosphate-limited chemostat containing mannitol/L-glutamate $/ \mathrm{NH}_{4} \mathrm{Cl}$, L-glutamate was transported by cells of MNF3841 at a rate of $2.8 \mathrm{nmol} \mathrm{min}^{-1}$ (mg protein) $)^{-1}$, which is $7 \%$ of the fully derepressed rate in an ammonia-limited chemostat. Assuming that protein represents $60 \%$ of the dry weight of the cell, this would allow an L-glutamate consumption rate of 
$-0.28 \mu \mathrm{mol} \mathrm{h}^{-1}$ (mg dry wt) $)^{-1}$, or $48 \%$ of the measured nitrogen consumption rate of cells grown in a chemostat containing mannitol/L-glutamate $/ \mathrm{NH}_{4} \mathrm{Cl}$, and considerably higher than the glutamate consumption rate measured. However, the transport rate represents an initial rate measured in cells washed with minimal salts, and is almost certainly higher than the steady-state rate of accumulation. It thus seems likely that the common amino acid carrier is regulated by repression and by inhibition of activity. The precise nature of the repressor is unknown, except that it is unlikely to be L-glutamate itself, since L-glutamate-grown cells have a fully derepressed rate of L-glutamate transport.

According to this study, free-living rhizobia are not defective in their ability to assimilate ammonia, a result compatible with the probable need to assimilate ammonia in the soil. While it is apparent that some strains of Rhizobium grown in laboratory culture may be defective in ammonia assimilation, they appear to represent the exception rather than the rule, and elaborate models of nitrogen regulation should not be based on such strains.

\section{REFERENCES}

BERGERSEN, F. J. (1961). The growth of Rhizobium in synthetic media. Australian Journal of Biological Sciences 14, 349-360.

Bergersen, F. J. \& Turner, G. L. (1967). Nitrogen fixation by the bacteroid fraction of breis of soybean root nodules. Biochimica et biophysica acta 141, 507515.

Bergmeyer, H. U., Bernt, E., Möllering, H. \& Pfleiderer, G. (1974). L-Aspartate and L-asparagine. In Methods of Enzymatic Analysis, 2nd edn, vol. 4, pp. 1696-1700. Edited by H. U. Bergmeyer. New York: Academic Press.

BERNT, E. \& BERGMEYER, H. U. (1974). L-Glutamate UV-assay with glutamate dehydrogenase and NAD. In Methods of Enzymatic Analysis, 2nd edn, vol. 4, pp. 1704-1708. Edited by H. U. Bergmeyer. New York: Academic Press.

BOTSFORD, J. L. (1984). Osmoregulation in Rhizobium meliloti: inhibition of growth by salts. Archives of Microbiology 29, 109-129.

Brown, C. M. \& Dilworth, M. J. (1975). Ammonia assimilation by Rhizobium cultures and bacteroids. Journal of General Microbiology 86, 39-48.

Brown, C. M., Macdonald-Brown, D. S. \& Meers, J. L. (1974). Physiological aspects of microbial inorganic nitrogen metabolism. Advances in Microbial Physiology 11, 1-52.

Chen, Y.-P., GlenN, A. R. \& Dilworth, M. J. (1984). Uptake and oxidation of aromatic substrates by Rhizobium leguminosarum MNF3841 and Rhizobium trifolii TA1. FEMS Microbiology Letters 21, 201205.

DilWorth, M. J., McKay, I., Franklin, M. \& GlenN, A. R. (1983). Catabolite effects on enzyme induction and substrate utilization in Rhizobium leguminosarum. Journal of General Microbiology 129, 359-366.

FAWCETT, J. K. \& SCOTT, J. E. (1960). A rapid and precise method for the determination of urea. Journal of Clinical Pathology 13, 156-159.

GleNN, A. R. \& DilworTH, M. J. (1981). The uptake and hydrolysis of disaccharides by fast- and slowgrowing species of Rhizobium. Archives of Microbiology 129, 233-239.

Glenn, A. R., Poole, P. S. \& Hudman, J. F. (1980). Succinate uptake by free-living and bacteroid forms of Rhizobium leguminosarum. Journal of General Microbiology 119, 267-271.

Kurz, W. G. W., Rokosh, D. A. \& LaRue, T. A. (1975). Enzymes of ammonia assimilation in Rhizobium leguminosarum bacteroids. Canadian Journal of Microbiology 21, 1009-1012.

LUDWIG, R. A. (1978). Control of ammonium assimilation in Rhizobium 32H1. Journal of Bacteriology 135, 114-123.

Mohapatra, S. S. \& Gresshoff, P. M. (1984). Carbonnitrogen requirements for the expression of nitrogenase activity in cultured Parasponia-Rhizobium strain ANU289. Archives of Microbiology 137, 58-62.

O'Gara, F. \& Shanmugam, K. T. (1976a). Regulation of nitrogen fixation by rhizobia - export of fixed $\mathrm{N}_{2}$ as $\mathrm{NH}_{4}^{+}$. Biochimica et biophysica acta $437,313-321$.

O'Gara, F. \& Shanmugam, K. T. (1976b). Control of symbiotic nitrogen fixation in rhizobia - regulation of $\mathrm{NH}_{4}^{+}$assimilation. Biochimica et biophysica acta 451, 342-352.

POOle, P. S., Dilworth, M. J. \& GlenN, A. R. (1984). Acquisition of aspartase activity in Rhizobium leguminosarum WU235. Journal of General Microbiology 130, 881-886.

Poole, P. S., Franklin, M., GlenN, A. R. \& DILWORTH, M. J. (1985). The transport of Lglutamate by Rhizobium involves a common amino acid carrier. Journal of General Microbiology 131, 1441-1448.

Ratcliffe, H. D., Drozd, J. W. \& Bull, A. T. (1983). The utilization of 5-oxoproline, ammonia and glutamine by Rhizobium leguminosarum in chemostat culture. Journal of General Microbiology 129, 17071712.

RAY, W. J. (1967). Photochemical oxidation. Methods in Enzymology 11, 490-497.

SCOTt, D. B., FARNDEN, K. J. F. \& Robertson, J. G. (1976). Ammonia assimilation in lupin nodules. Nature, London 263, 703-705.

Smart, J. B., Dilworth, M. J. \& Robson, A. D. (1984). Effect of phosphorus supply on phosphate uptake and alkaline phosphatase activity in rhizobia. Archives of Microbiology 140, 281-286.

TUBB, R. S. (1976). Regulation of nitrogen fixation in Rhizobium sp. Applied and Enviromental Microbiology 32, 483-488. 